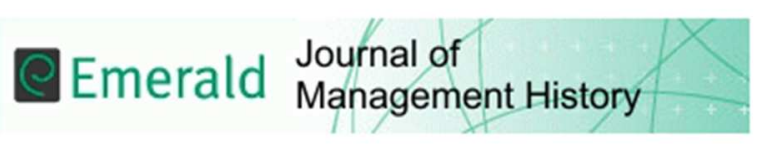

\title{
From Corner Store to Superstore: A Historical Analysis of Sainsbury's Co-Evolution
}

\begin{tabular}{|r|l|}
\hline Journal: & Journal of Management History \\
\hline Manuscript ID & JMH-04-2017-0017.R1 \\
\hline Manuscript Type: & Research Paper \\
\hline Keywords: & Co-evolution theory, Sainsbury's, Sainsbury \\
\hline \multicolumn{2}{|l}{} \\
\hline
\end{tabular}

SCHOLARONE $^{\text {m }}$
Manuscripts 


\title{
From Corner Store to Superstore: A Historical Analysis of Sainsbury's Co-Evolution
}

\begin{abstract}
:
Purpose - The purpose of this study is to explore the conceptualisation of co-evolution using a corporate history research approach. While the application of the co-evolutionary perspective to the organisational-environmental relationships has uncovered significant evidences, little is understood about how the co-evolutionary process occurs over time between organisations and their institutional environment.
\end{abstract}

Design/methodology and approach - A co-evolutionary corporate history approach in employed as we investigated Sainsbury's historical trajectory, exploring the role specific family members played in the evolution of the firm and the co-evolution of Sainsbury with its environment. This research design framework encompasses longitudinal archival analysis which incorporates both external and internal engagement which fostered Sainsbury's joint evolution.

Findings - Findings from this study clearly suggests that certain organisations can and do co-evolved with their environment. However, organisations need to build legitimate cases for co-evolution to occur. In addition, they need to acquire certain resources that can be employed to stimulate changes within their institutional environment.

Originality/value - Through a corporate history archival analysis, this study presents a UK company's, evolutionary narrative. The authors contribute to the growing literature on coevolution in management studies by presenting a detailed historical narrative and interpretation of Sainsbury's evolution at different time periods.

Keywords Co-evolution, Family Business, Sainsbury

Paper type Research Paper 


\section{From Corner Store to Superstore: A Historical Analysis of Sainsbury's Co-Evolution}

\section{Introduction}

The co-evolutionary perspective acknowledges that organisational and environmental changes occur in a simultaneous and interactive manner. A key position from the coevolution studies is that organisational adaptation and environmental selection activities are complementary. While organisations adapt to changes within their institutional environment, through strategic choice and managerial intent, simultaneously they can bring about institutional change for their own gain (Garcia-Cabrera and Durean-Herrera, 2016; Luse and Mennecke, 2014; Murmann, 2013).

The application of the co-evolutionary perspective to the organisationalenvironmental relationships, has uncovered significant evidences to support the position that organisations by developing institutional capacities propagate change within their institutional environment. Such capabilities included transforming themselves into pseudoinstitutions (Dielemans and Sachs, 2008), building supportive political networks (Rodrigues and Child, 2003) and creating subsidiary agencies (Cantwell et al., 2010). While the types of organisational capacities are well documented in the literature, little is understood about how the co-evolutionary process occurs over time (Child et al., 2013; Carcia-Cabrera and DuranHerrera, 2016; Murmann, 2013). Hence this study asks: how can an organisation co-evolve with its institutional environment?

There is a clear argument within the literature (Dieleman and Sachs, 2008; Rodrigues and Child, 2008b; Child and Rodriques, 2011) that the manifestation of 'power' between organisations and their environment during the co-evolutionary process needs to be investigated. By examining 'power' as a form of institutional capacity, it allow us to provide additional insight about the role that organisational actors during a co-evolution process (Carney and Gedajlovic, 2002; Child et al., 2013). It also enables us understand the conditions which enable organisations to become catalysts of institutional change. We revisit 
the co-evolutionary perspective and focus on how an individual organisation co-evolved with its environment. This study focuses on the UK supermarket chain, Sainsbury's PLC (Sainsbury's hereafter). The Sainsbury story provides a unique opportunity to examine how organisational and environmental changes are bi-directional, interactional and mutually influencing and continually evolving. It enables us to understand how a single organisation and its constituent parts, both internal and external (for example, suppliers, competitors and regulators), co-evolve with each other and with an ever-evolving environment. More specifically, this study investigates: how Sainsbury's co-evolved with its institutional environment and how the co-evolution process evolved.

The remainder of this paper is structured as follows. The subsequent section introduces the theoretical background which underpins the study. Thereafter we provide a brief overview of the history of Sainsbury's PLC. The methodology and a narrative around the co-evolution of Sainsbury's PLC is presented after this. Finally, key findings and conclusion of this study are presented in the penultimate and final chapter respectfully.

\section{Theoretical Background}

The concept of co-evolution provides an expansive framework to enable us to understand the complex and dynamic interactions between organisations and their environments (Lockett et al., 2013). By drawing our attention to the interaction of forces emanating from the organisations' external environment, it enables us to understand how organisations respond and shape their external environment to their own advantage (Child et al., 2013). More specifically, it illustrates the long-term and interdependent nature of these interactions

(Dieleman and Sachs, 2008) and argues that institutional outcomes are a result of 'managerial actions, institutional influences and extra-institutional changes' (Lewin et al., 1999, p. 535). 
The co-evolutionary framework explicitly addresses the long-term two-way interaction which can exist between an organisation and its environment (Dieleman and Sachs, 2008). The co-evolutionary process create situations in which simultaneous changes are instigated by both actors (Murmann, 2000).

Organisations employ resources to influence institutionalised norms within their environment. The extent to which organisations are able to disseminate change within their institutional environment is inherently related to their position of 'power' they hold within their environment (Child et al., 2012; Child et al., 2013; Dieleman and Sachs, 2008; Rodrigues and Child, 2003; Rodrigues and Child, 2008b). We identify 'power' as the ability of an organisation to employ specific resources to bring about changes within their institutional environment (Child and Rodrigues, 2011) or to resist new ones (Hardy and Clegg, 1996). Organisations utilise their power within a joint-evolution to build competitive advantages through negotiation and alignment of interests with institutions (Child et al., 2013; Lawton, et al., 2013; Sun et al., 2010; Oliver and Holzinger, 2008).

\section{Sainsbury's: A Brief History}

Sainsbury's was founded in 1869 by John James and Mary Ann Sainsbury who opened a small shop to sell milk, eggs and butter. This small undertaking based in Drury Lane, London contained in embryonic form some of the key ingredients of the modern supermarket (Bevan, 2005). From the very beginning the Sainsbury's family set out to distinguish themselves from food shops trading in the area.

Throughout the 150 years of trading the organisational has faced pressure from its institutional environment. Sainsbury's is prime example of an organisation who simultaneously adapt to and influence the external environment. The company often turned the adverse trading conditions of the post-war period to its advantage and harnessed a new consumer age which involved foreign travel, the introduction of refrigeration and television 
(Emerson, 2006). Managerial decisions and the intent to be the best has led to diversification, innovation and the setting of standards which have been adopted by the whole retail industry. Sainsbury's led the way amongst British food retailers in the development of self-service and the introduction of the supermarket concept.

Four generations of the family have been involved within the company which has included the appointment of six chairmen. Each successive chairman continued to build on the original concepts of the founders and continued the trend to be the best at what they did. Sainsbury's was wholly owned by the Sainsbury family until 1973, when it underwent public floatation (Salmon, 2004a). Executive responsibility was retained until 1999, when David Sainsbury retired from the company. While none of the Sainsbury family is directly involved with the management of the business, they continue to maintain a close interest in the company.

Not only did the Sainsbury family play important roles in the development of the company, they influenced the social, cultural and educational life of Britain (Seth and Randall, 2011). Current interests of the family include business, politics, philanthropy, the arts and science. In 1992 Sainsbury's was the most profitably retailer in the UK (Emerson, 2006), with profits in the region of $£ 628$ million (J Sainsbury PLC, 1992). This made Sainsbury's not only the most profitable food retailer in the UK, but also the most profitable retailer in Britain (Emerson, 2006). The retailer, including its hypermarket subsidiary Savacentre, had a share of around $10 \%$ of each market it operated within. Sainsbury's is based on a corporate culture which reflects a long history of family ownership and customer loyalty.

\section{Data and Methodology}

A framework for studying co-evolution has been developed by Lewin and Volberda (1999). Their framework encompasses longitudinal analysis which incorporates both external and 
internal forces which fosters co-evolution between organisations and their institutional environment. We adopted the co-evolutionary framework developed by Lewin and Volberda (1999) to examine how Sainsbury's has evolved with its environment. Sainsbury's provides a unique opportunity to examine the interaction between Sainsbury's and its micro and macro environments. In particular we employed a 'corporate history research genre' (Delahaye et al., 2009) which enabled us to rich narrative around a single corporate entity. Our period of investigation focuses on the period 1869 to 1991 . We are also able to explore the key role family members have played in this period and gain an understanding into the role organisational power plays within the co-evolution process.

A variety of sources were utilised while undertaking this research. During the course of the research, the authors visited the Sainsbury Archive which is based at the London Docklands Museum. The archive provided access to a wide range of resources including annual reports, JS Journals and other corporate documentation. Other secondary sources such as the Sainsbury's online archive, newspaper extracts and historical accounts of Sainsbury's development (e.g. Emerson, 2006; Williams, 1994). This longitudinal data was collected over the period January 2010 to December 2014.

\section{Data Analysis}

The data collected consisted of chronologically order events, activities and managerial decisions. The data was classified using periodisation (Rowlinson et al., 2014). Using periodisation allowed environmental events to be viewed from viewpoint of the organisation (Greenwood and Benardi, 2014). The data was analysed drawing on methods suggested by Langley (1999) for longitudinal research. First, a narrative of events, managerial decisions, external and internal factors was developed. Second, we employ Langley's (1999) temporal bracketing strategy. A temporal bracketing strategy involves the decomposition of events into successive eras which are separated by discontinuities (Chiles et al., 2004). We therefore 
used the temporal bracketing strategy to separate the longitudinal data into four distinct periods. These periods are established based on the chronological order of events occurring over the period 1896-1991. Each period is separated by a major break, thus allowing for analysis and replication of theoretical ideas (Langley, 1999).

The first period, from 1869-1913, was labelled 'The Early Years'. This period encompasses the formative years of Sainsbury's. This period allows us to examine the humble beginnings of the company and gain an understanding of the family values and ethos. The second period, from 1914-1949, was labelled 'Surviving the World Wars'. This epoch demonstrates how Sainsbury's had to co-evolve with its external environment to ensure its own survival. This period also allows us to gain some understanding in the importance of building social networks and building organisational power. The third period, is called 'Leading the way' and covers the period 1950-1969. This period documents how Sainsbury's were able to rebuild following on from the war years. By being innovative and building on organisational power gained during the previous period, they were able to bring about significant change to the UK retail food market. The final period, entitled 'The hey days' focuses on the last period of significant family ownership. This period was characterised by economic boom and stability which filtered into the socio-emotional wealth of the family. Based on our contextual knowledge of co-evolution and the historical development of Sainsbury's, we able to assign meaning to the archival data. The analysis of each period is presented below.

\section{Period 1: The Early Years (1869-1913)}

Sainsbury's origins began in 1869, when John James Sainsbury and his wife Mary Ann, opened a small dairy shop in Drury Lane. The couple promised to supply good quality products at low prices and from the beginning attempted to differentiate themselves from the vast amounts of neighbouring competitors.

\section{Transforming the Quality of British Food}


British retailing in mid-nineteenth century was extremely complex. Retailing was based around the traditions associated with producer-retailers and buyer-retailers and the products they sold (Williams, 1994b). Producer-retailers sold fresh home-produced products. While, buyer-retailers sold non-perishable products which had been purchased through a wholesaler network. Sainsbury's began as a producer-retailer and it is this background which gave Sainsbury's a competitive advantage in the food retail sector and what drove its corporate identify.

Product development and quality control was the responsibility of the product-retailer. Hygiene standards were low and the quality of products poor. From the very beginning, the Sainsbury Family had a very clear moto, 'Quality perfect, prices lower'. They wanted to differentiate themselves from their competition by offering good quality products, produced and sold under extremely hygienic conditions. By exploiting advantages in quality and incorporating the image of their 'own brand' into the business (Williams, 1994b), the family was able to shape a corporate identity and philosophy which would continue to provide them with a competitive advantage over their rivals.

The early development of brand identity proved to be critical for survival in later years. As it enabled the Sainsbury family to be successful, diversifying their product range. John James and Mary Ann has a very clear idea about how they perceived that their small offering should be and how they could differentiate themselves from other similar stores. The couple offered a very distinctive shopping environment. While other grocery stores offered a very limited range of products and targeted the working class. The family choose to operate across a wide range of locations, target not only the working class but also the middle classes. Different stores began to diversify their offerings, thus appealing to their target market. By 1882, the family had begun to offer a wider range of products within their store. How the products which they offered had to be of significant quality. John James wanted to ensure that 
all of the products sold within his shops were fresh. His desire to ensure the freshness of his products led him to insisting that his Dutch supplier stamped every pad of butter with the date it was produced (Sainsbury's, 2015). This was an extremely innovative approach to food manufacturing. This innovation was later adopted by the Dutch government who made it compulsory for all butter manufacturers to stamp their products with the manufacturing date.

John James continued to find methods of providing good quality products at prices lower than his competitors. The simplest way of ensure good quality products was to move into production. This meant producing your own cooked meats or pies. Sainsbury's choose to integrate their supply chain further and purchased a farm to supply meat. The farm was managed by Frank, the third son of the founders (Williams, 1994b). This enable the family to have even greater control over the quality of their products. By 1912, the Family had branched into the collect of eggs. Again, this was to promote the culture of selling quality products within the firm.

One of the key drivers of the evolution of Sainsbury's a food retailer was the family itself. The firm grew out of the founder's desire to open one store for every child, which led to a target of twelve stores in total. Every son took a position within the organisation. From an early age the Sainsbury children were involved within the running of the stores. Mr John Benjamin (Mr JB), the first son of John James and Mary Ann commented:

'I remember wearing a small white apron (made especially for me by my mother) to fill the position of 'Egg Boy' in the shop on Saturdays. How proud I was to be able to bank out of my wage of one shilling and sixpence [7.5p] for services rendered!' (Sainsbury's Archive)

From the role of 'Egg Boy', Mr JB progressed to run the firm as a partnership with his father from 1915, becoming a director in 1922 and finally chairman in 1928. He continued to pioneer the introduction of branded products into Sainsbury's stores. In 1938, Mr JB was succeeded by his two sons, Alan and Robert. 
Organisations' initial conditions particularly their identity exert pressures on their how they co-evolve with the environment (Child et al., 2012). The initial conditions of organisations influence their maintenance of taken-for-granted organisational practices regardless of changes within their institutional environment. Sainsbury's heritage of family ownership and community engagement drove how it subsequently co-evolved with its environment.

\section{Period 2: Surviving the World Wars (1914-1949)}

The Second World War, in particular, impacted on Sainsbury's progress (Emerson, 2006). After the war ended the main concern of the family was to rebuild the firm's damaged trade and to begin the process of modernising the business. While, this period bought about significant challenges to the family, they continued to maintain their standards and to evolve their business.

During World War 2, the fall in sales was so significant that it led to Robert Sainsbury to comment 'If sales had gone any lower, we [Sainsbury's] couldn't have survived' (Emerson, 2006, p.29). The challenging environment meant that the family had to be resourceful and show resilience, while combatting the inevitable food shortages and the rising cost of goods. Throughout the war years, Sainsbury's continued to support the community in which their stores were embedded. Good relationships were maintained with their employees, who were made to feel valued and provided with security. John James Sainsbury donated significant amounts of how own funds towards the war effort (Sainsbury's, 2015).

The war years was characterised by food rationing and price controls. In October 1917, the Ministry of Food introduced food rationing and price controls to ensure the availability of staple food products for all citizens but more importantly to ensure fair prices.

The Sainsbury family did not agree with the price controls. The family had developed a reputation for selling a large variety of high-quality fresh produce at low prices. Introducing 
price controls and rationing meant for Sainbury's an erosion of their competitive advantages.

The commitment of Sainsbury's to ensure that prices were kept low meant they were often threatened with prosecution from the Board of Trade for refusing to comply with price rises (Sainsbury, 2015b). In one of their adverts placed during this time period, Sainsbury's noted that:

\begin{abstract}
"Sainsbury's Threatened with Prosecution for Selling Too Cheaply!!: Content with a small margin of profit, it has been our custom to pass on to our customers the benefit of lower prices obtainable by our organization. The Ministry of Food refuse to allow us to enjoy the customary rebate on our cash transactions or the savings effected by our large purchases. They compel us to raise prices to disadvantage of our hundreds of thousands of our customers" (The Times, 1918).
\end{abstract}

However, the impact of war affected Sainsbury's more than its rivals (Emerson, 2006). Nonetheless, wherever possibly, Sainsbury's kept price below the recommendations made by the Ministry of Foods. For instance, Sainsbury's was able to keep their eggs below recommended prices. This was possible due to their backward integration into the supplychain. In 1902, the youngest son of John and Mary-Ann, Frank set up a poultry farm to directly supply the family stores with fresh eggs. The provision of fresh eggs, by Frank Sainsbury, made stores less dependent on state intervention in the setting of prices.

The First World War led to a shortage of skilled labour. Stores were put under significant pressure as many, of their predominantly male, staff left their positions to sign-on and join the war effort. The family business continued to show its dedication, support and commitment to the welfare of their staff and their families. A statement was issued, by Mr JB, to all departing staff which assured them that they would be able to return to their positions once the war was over (Sainsbury's, 2015b). To ensure that the company could continue trading, the family recruited women to fill the vacancies left by male colleagues who had joined the war-effort. Sainsbury advertised for 200 women to join the company, which 
promoted thousands of applicants. A training school was established at the Blackfairs headquarters, enabling new employees to learn about the values and identity of the firm, as well as, obtaining the required skills to be able to undertake roles within the company.

Sainsbury's tradition of engaging with the local community served to enhance their reputation with the general public. From the very beginning the family business was keen to integrate itself within the wider community. This desire to be part of the community led Sainsbury's to position itself as a source of information, advice and education to its customers (Emerson, 2006).

In 1939, with the onset of rationing, households were required to register with a local retailer. Sainsbury set about putting their stores at the centre of the local communities they served. Adverts were placed in national newspapers providing advice on rationing and emphasizing the variety of goods that were available within their stores. In addition, the assisted the local community with completing the required paperwork needed to register. In the wake of food shortages, Sainsbury's introduced a "Fair Shares" point scheme. The "Fair Shares" scheme was designed to enable products in short supply to be distributed equitably. Customers were allocated a number of points according to the number of rationed food products they had registered for. The scheme encouraged customers to register and obtain all rationed food products from Sainsbury's. Adults were allocated a maximum of 16 points per four-week period which they could trade for goods covered by the scheme. Later, the UK Ministry of Foods introduced a similar point scheme.

\section{Period 3: Leading the Way (1950-1969)}

In post-war years, British retailers drew heavily on the US retailing experience; importing retailing methods, technology and merchandise (Shaw et al., 2004). Retail trading stamps, was a method of establishing customer loyalty, again an idea originating from the USA. Sainsbury's however was against the adoption of trading stamps. Stamps raised costs for 
retailers. Obviously, this would mean that retailers would either have to absorb the costs or recover them from customers. During the period, 1960-1963, profit margins for grocers were being significantly squeezed (Morelli, 1998). At a time when capital was required for new investment, to establish supermarkets and self-service, profits were being squeezed.

Sainsbury's were responsible for initiating and co-ordinating a campaign against trading stamps. Utilising their industry position, Sainsbury's immediately rejected the use of trading stamps. Alan Sainsbury argued that '...the stamps [w]as a dishonest gimmick which benefited neither customers nor retailers, but merely added to the costs of distribution, which were ultimately passed on to consumers through higher prices.' (Salmon, 2004b).

He went on to form the Distributive Trades Alliance (DTA). The DTA was formed in order to co-ordinate the opposition to the emergence of trading stamps amongst all sectors of the retail industry (Morelli, 1998). Sainsbury's were joined by other major retailers in the UK including Marks and Spencer, Boots, WH Smiths and John Lewis. Manufacturers were also concerned about the introduction or trading stamps. The Food Manufacturers' Federation (FMF) contacted Alan Sainsbury in 1963 to ask for help in putting manufacturers' point of view forward. Furthermore, Alan drew on his political power by sponsoring a bill in the House of Lords. The bill called for controls on advertising and to allow stamps to be exchanged for cash. Eventually the bill was passed and the Trading Stamps Act of 1964 was introduced. Not satisfied with having his bill passed into law, Alan continued to wage war against trading stamps. Investing company money in anti-trading stamp media campaign. In 1967 a series of full-page advertisements were commissioned in national newspapers. In line with their role of educators, leaflets were produced for customers explain their firm's opposition. The leaflet stated, that 'Sainsbury's makes no bones about it ... it would be impossible for Sainsbury's to maintain their high standards of quality and freshness and give trading stamps without raising prices' (Sainsbury’s Archive, 2012). 
The government's desire to increase productivity levels encouraged British retailers to adopt American retailing techniques (Anglo-American Council, 1950). Self-service had been introduced in the USA during the Great Depression of the 1930s, stimulated by the desire to cut costs and reduce prices. In the UK, the desire to introduce self-service arose due to the need to relieve issues associated with post-war such as labour shortages. Morelli (1998) argues that it was the co-operative movement which pioneered and dominated the movement towards self-service stores in the UK. However, Sainsbury's role in the adoption of selfservice and the introduction of supermarket retailing.

In 1949, Alan Sainsbury and his assistant Fred Salisbury travelled to the US to study self-service methods. As documented by Williams (1994b:125), they 'came back so thrilled and stimulated at the potentiality if self-service trading that we became convinced that the future lay with what we thought were large stores of 10,000 sq ft of selling space'. However, the first self-service store opened in Croydon was a more modest 3,300 square feet, which was extremely large by British standards. The Sainsbury Family has been very forward thinking in their development and had from an early stage thought about the structure of their business. The early centralisation of their operations gave them a first-mover advantage in the creation of supermarket retailing and the adoption of self-service. The producer-retail origins of Sainsbury's had assisted them in obtaining the manufacturing and production capabilities which would be required of a national provider. In 1949, the Ministry of Foods, offered special building licenses to those retailers who were willing to experiment with self-service trading. Initially, one hundred licenses were offered, however, due to the challenging postwar trading environment the take-up was very limited (Williams, 2007). Naturally, inspired by what had been observed in the US, Sainsbury's took up the offer. By the mid-1960s, a full commitment had been made by the company to replace all their counter service stores with self-service stores (Williams, 2007). 
The British poultry industry predominantly emerged through the innovations of food retailers. 'In Britain, the role of innovator and co-ordinator fell to a small group of entrepreneurial poultry farmers and a handful of highly innovative food retailers, with one $\mathrm{J}$ Sainsbury's leading the way' (Godley and Williams, 2007:2-3).

Sainsbury's continually played a role in changing the perceptions of the public to a range of issues. Sainsbury's invested in persuading the public to eat chicken. In 1958, they attempted to shake off the perception that chicken was a luxury product, with a campaign of "Chicken is Cheap" (Emerson, 2006). As the market began to mature, Sainsbury's reacted by launching new products.

\section{Period 4: The Hey Day (1970-1991)}

The 1970s were characterised by economic instability, frequent strikes and low productivity. Food retailing was one of the sectors which was heavily affected. As the market leader, Sainsbury's was continually under pressure to continue to both the style and pace of development of the food retail within the United Kingdom. This chapter of Sainsbury's history was characterised by heavy political lobbying and building organisational power through networking. Based on observations from food retailing in the US and Europe, the family had a clear vision about how the future of retailing within the UK. While they had the vision, barriers remained in the form of planning restrictions.

In an attempt to appeal to planners, Sainsbury's engaged in a series of meetings and consultations. In 1969, Timothy Sainsbury made a speech to the Royal Institute of Chartered Surveyors which illustrated how planning attitudes had failed to shift, despite the need to rejuvenate town centres and change consumer preferences. 'In this country, we are very backward in providing information which would enable planners and retailers alike to make better decisions, both as to the siting of shops and to their size and number. We have a 
planning system which is designed to prevent bad building; unfortunately, it also acts as a deterrent to imagination and to design and innovation.' (Emerson 2006, p. 104).

The Sainsbury family continued to use their substantial networks to influence relevant parties. In October 1970, JD Sainsbury argued at the Marketing Society Conference in October 1970, '...Serving a large area and designed for the car shopper, with as comprehensive a range of large and small shops, department stores and supermarkets as most important high streets' (Emerson 2006, p. 210). Furthermore, Sainsbury's organised a special two-day seminar at St. John's College, University of Cambridge. The seminar was entitled 'Retail store location in the 1970 s' and both JD and Timothy Sainsbury spoke. This is a further example of the Family's desire to build networks and gain social 'power'. Once again, they demonstrated the desire to take of responsibilities which were beyond the remit of their individual roles within the company. By the end of the 1980 s, due to retirements, it became necessary for changes to be made to the board. Since 1967, the company had been chaired by Alan, who had taken a very proactive role within the company. He had given the company direct and through his ideas and innovations shaped food retail.

\section{Discussion of Findings}

This study has investigated how a single organisation has evolved from small humble beginnings into a large well-established organisation. Building upon the founders' original mission of selling quality products at reduced prices, has allowed the company to build a very strong corporate identity. Through the historical analysis of Sainsbury, it is clear that the firm co-evolved with its institutional environment by employing specific organisational resources to engender institutional change. The Family's interest in the wider community and politics enable them to build organisational power which could be used to influence their institutional environment. Each of the four generations of the Sainsbury family involved within the firm, each had a very important role to play in the evolution of firm and its overall success. Each 
family member can be viewed as an organisational actor with the ability to influence institutional change. What comes over clearly is each member of the family used their social networks and positions to engender change. Alan Sainsbury's abiding interest in politics, ensured that he was sensitive to general changes in society (Emerson, 2006). The social position of family member such as Alan Sainsbury allowed the firm to influence its external environment.

\section{References}

Alexander, A., Nell, D., Bailey, A.R. and Shaw, G. (2009), "The co-creation of a retail innovation: shoppers and the early supermarket in Britain", Enterprise and Society, Vol. 10 No. 03, pp. 529-558.

Anglo-American Council (1951), "Anglo-American Council on Productivity: Report of a Specialist Team which Visited the United States of America in 1950" Productivity Report

Berger, B.K., (2005), "Power over, power with, and power to relations: Critical reflections on public relations, the dominant coalition, and activism". Journal of Public Relations Research Vol 17 No 1, pp. 5-28.

Bevan, J., (2005). Trolley Wars: The Battle of the Supermarkets. Profile

Beveridge, W.H. (1943), The Beveridge report in brief, HM Stationery Office.

Carney, M., and Gedajlovic, E. (2002), "The co-evolution of institutional environments and organizational strategies: The rise of family business groups in the ASEAN region" Organization Studies, Vol 23 No 1, pp. 1-29.

Cantwell, J., Dunning J.H., and Lundan, S.M. (2010), “An evolutionary approach to understanding international business activity: The co-evolution of MNEs and the institutional environment”. Journal of International Business Studies Vol. 41 No. 4, pp.567-586.

Child, J. (1972), "Organizational structure, environment and performance: The role of strategic choice”. Sociology Vol. 6 No 1, pp.1-22.

Child, J., and Rodrigues, S.B. (2011) "How organizations engage with external complexity: A political action perspective". Organization Studies Vol. 32 No. 6, pp.803-824.

Child, J., Rodrigues S.B., and Tse K.K.T. (2012), “The Dynamics of Influence in Corporate Co-Evolution”. Journal of Management Studies Vol. 49 No 7, pp.1246-1273.

Child, J, Tse K.K.T., and Rodrigues, S.B. (2013), The Dynamics of Corporate Co-evolution: A Case Study of Port Development in China, Cheltenham: Edward Elgar. 
Chiles, T.H., Meyer, A.D., and Hench. T.J. (2004), "Organizational emergence: The origin and transformation of Branson, Missouri's musical theatres". Organization Science Vol. 15 No. 5, pp. 499-519.

Clegg, S.R., Courpasson, D., and Phillips, N. (2006), Power and organizations. Pine Forge Press.

Delahaye, A., Booth, C., Clark, P., Procter, S., and Rowlinson, M. (2009), "The genre of corporate history". Journal of Organizational Change Management Vol. 22 No. 1, pp.27-48.

Dieleman, M. and Boddewyn, J. J. (2012), "Using organization structure to buffer political ties in emerging markets: A case study. Organization Studies Vol. 33 No. 1, pp.71-95.

Dieleman, M. and Sachs, W.M. (2008), "Coevolution of institutions and corporations in emerging economies: How the Salim group morphed into an institution of Suharto's crony regime". Journal of Management Studies Vol. 45 No. 7, pp.1274-1300.

DiMaggio, P.J. and Powell. W.W. (1983), "The iron cage revisited: Institutional isomorphism and collective rationality in organizational fields". American sociological review Vol 48 No. 2, pp. 147-160.

Djelic Marie-Laure and Ainamo Antti (1999), "The Coevolution of New Organizational Forms in the Fashion Industry: A Historical and Comparative Study of France, Italy, and the United States". Organization Science Vol. 10 No. 5, pp. 622-637.

Emerson G. (2006). Sainsbury's: The Record Years, 1950-1992. Haggerston Press.

Greenwood, A. and Bernardi, A. (2014), "Understanding the rift, the (still) uneasy bedfellows of History and Organization Studies". Organization Vol 21 No. 6, pp. 907-932

Godley, A. and Williams, B. (2007), "The chicken, the factory farm and the supermarket: the emergence of the modern poultry industry in Britain", Economics \& Management Discussion Papers em-dp2007-50, Henley Business School, Reading University, Reading, UK.

Godley, A. and Williams, B. (2011), "Democratizing Luxury and the Contentious "Invention of the Technological Chicken" in Britain”. Business History Review, Vol. 83 No. 02, pp. 267290.

Hosking, P. (1993), "Leader of the Family Pack: David Sainsbury has a surfeit of relatives minding his store". The Independent, 11 April 1993

Hutzschenreuter, T., Pedersen, T., and Volberda, H.W. (2007), "The role of path dependency and managerial intentionality: A perspective on international business research". Journal of International Business Studies, Vol. 38 No. 7, pp. 1055-1068.

Kondra, A.Z. and Hinings, C.R. (1998), "Organizational diversity and change in institutional theory”. Organization studies Vol. 19 No. 5, pp.743-767.

Jones, C. (2001), "Co-evolution of entrepreneurial careers, institutional rules and competitive dynamics in American film, 1895-1920”. Organization Studies Vol. 22 No. 6 pp. 911-944. 
Kolk, A., and Tsang, S. (2017), "Co-evolution in relation to small cars and sustainability in China: Interactions between central and local governments, and with business". Business \& Society, Vol. 56 No. 4, pp. 576-616.

Koza, M.P. and Lewin, A.Y. (1999), "The coevolution of network alliances: a longitudinal analysis of an international professional service network". Organization Science Vol. 10 No. 5 pp. 638-653.

Langley, A. (1999). "Strategies for theorizing from process data". Academy of Management Review Vol. 24 No. 4 pp. 691-710.

Lawton, T., McGuire, S., and Rajwani, T. (2013). "Corporate political activity: A literature review and research agenda". International Journal of Management Reviews Vol. 15 No. 1 pp. 86-105.

Lewin, A.Y., Long C.P., and Carroll, T.N. (1999). "The coevolution of new organizational forms". Organization Science Vol. 10 No. 5 pp. 535-550.

Lewin, A.Y. and Volberda, H.W. (1999), "Prolegomena on coevolution: A framework for research on strategy and new organizational forms". Organization science, Vol. 10 No. 5, pp. 519-534.

Lockett, A., Wright, M., and Wild, A. (2013), "The co-evolution of third stream activities in UK higher education”. Business History, Vol. 55 No. 2, pp. 236-258.

Luse, A. and Mennecke, B. (2014), "IT can matter: co-evolution fostering IT competitive advantage”. Management Research Review, Vol. 37 No. 6, pp. 574-588.

Madhok, A. and Phene, A. (2001), "The co-evolutional advantage: strategic management theory and the eclectic paradigm". International Journal of the Economics of Business Vol. 8 No 2 pp.243-256.

March, J.G. (1991). "Exploration and exploitation in organizational learning”. Organization science, Vol. 2 No. 1 pp. 71-87.

Morelli, C. (1998), "Constructing a balance between price and non-price competition in British multiple food retailing 1954-64”. Business History, Vol. 40 No. 2 pp. 45-61.

Morelli, C. (1999), "Information costs and information asymmetry in British food retailing", Service Industries Journal, Vol. 19 No. 3, pp. 175-186.

Morelli, C. (1997), "Britain's Most Dynamic Sector? Competitive Advantage in Multiple Food Retailing", Business and Economic History, Vol. 26 No. 2, pp. 770-781.

McKelvey, B. (1997), "Perspective-quasi-natural organization science". Organization Science Vol 8 No. 4, pp. 351-380.

Murmann, J.P. (2000), "Knowledge and competitive advantage in the synthetic dye industry, 1850-1914: The coevolution of firms, technology, and national institutions in Great Britain, Germany, and the United States". Enterprise and Society Vol. 1 No 4 pp.699-704.

Murmann, J.P. (2013). The coevolution of industries and important features of their environments. Organization Science Vol. 24 No 1 pp. 58-78. 
Oliver, C. and Holzinger, I. (2008) "The effectiveness of strategic political management: A dynamic capabilities framework". Academy of Management Review Vol. 33(2): 496-520.

Petrick, G.M. (2010), "Food Chains: From Farmyard to Shopping Cart by Warren Belasco and Roger Horowitz (eds)", Food, Culture \& Society, Vol. 13 No. 3, pp. 458-460.

Rodrigues, S. and Child, J. (2003), "Co-evolution in an Institutionalized Environment". Journal of Management Studies Vol. 40 No. 8, pp. 2137-2162.

Rodrigues, S. and Child, J. (2008a), "The development of corporate identity: a political perspective". Journal of Management Studies Vol. 45 No. 5, pp. 885-911.

Rodrigues, S.B. and Child, J. (2008b), Corporate Co-evolution: A Political Perspective. Chichester: Wiley.

Rowlinson, M., Hassard, J., and Decker S. (2014), "Strategies for organizational history: A dialogue between historical theory and organization theory". Academy of Management Review Vol. 39 No. 3, pp. 250-274

Salmon B (2004), "Sainsbury, Alan John, \& Baron Sainsbury (1902-1998) Oxford Dictionary of National Biography”, Oxford University Press, 2004; online ed, Jan 2010 [http://www.oxforddnb.com/view/article/71184, accessed 3 Dec 2012]

Sainsbury's Archive (2015a), "Museum of London - The second generation (1)". Available: http://archive.museumoflondon.org.uk/SainsburyArchive/Themes/People/Sainsburys/Second gen1.htm [2015, 11/18/2015].

Sainsbury's Archive (2015b), "Museum of London - The second generation (2)". Available: http://archive.museumoflondon.org.uk/SainsburyArchive/Themes/People/Sainsburys/Second generation2.htm [2015, 11/18/2015].

Sainsbury's (2015a), "Our Story - Sainsbury's History 1869 to 1900 | Sainsbury's Archive. Available: $\quad$ http://www.sainsburyslivingarchive.co.uk/collections/sainsburysheritage/sainsburys-humble-beginnings-1869-1900 [2015, 11/18/2015].

Sainsbury's (2015b), Sainsbury's Colleagues: Serving Britain For 145 Years. Available: http://www.sainsburyslivingarchive.co.uk/collections/sainsburys-heritage/sainsburys-145thbirthday [2015, 11/18/2015].

Sainsbury's (2015c), Sainsbury's Face Fresh Challenges: 1900-1914. Available: http://www.sainsburyslivingarchive.co.uk/collections/sainsburys-heritage/sainsburysheritage-1900-1914 [2015, 11/18/2015].

Sainsbury's (2015d), Sainsbury's Through World War I. Available: http://www.sainsburyslivingarchive.co.uk/collections/world-war-i-centenary/sainsburysthrough-world-war-i [2015, 11/18/2015].

Sainsbury's (2015e), Serving the Nation Since 1869. Available: http://www.sainsburyslivingarchive.co.uk/collections/sainsburys-heritage/serving-nation$1869[2015,11 / 18 / 2015]$.

Sainsbury, (2000) J Sainsbury PLC: Annual Report and Accounts 2000. Available at <http://www.j-sainsbury.co.uk/media/218407/ar2000rev.pdf> 
Scott, W.W.R. (2013). Institutions and organizations: Ideas, interests, and identities. Thousand Oaks, CA: Sage.

G. Shaw, Curth, L. and Alexander, A. (2004), "Selling self-service and the supermarket: the Americanisation of food retailing in Britain, 1945-60", Business History, Vol. 46 No 4 pp. $568-582$

Suhomlinova, O. (2006), Toward a Model of Organizational Co $\square$ Evolution in Transition Economies. Journal of Management Studies Vol. 43 No 7 pp. 1537-1558.

Sun, P., Mellahi, K., and Thun, E. (2010), "The dynamic value of MNE political embeddedness: The case of the Chinese automobile industry". Journal of International Business Studies Vol. 41 No. 7 pp. 1161-1182.

Tessari, A. and Godley, A. (2014), "Made in Italy. Made in Britain. Quality, brands and innovation in the European poultry market, 1950-80", Business History, Vol. 56 No. 7, pp. 1057-1083.

The Times (1918), “Sainsbury's Threatened with Prosecution for Selling Too Cheaply!!”. The Times, 24 May 1918

Van der Lugt, L.M., Rodrigues, S.B. and Van den Berg, R. (2014), "Co-evolution of the strategic reorientation of port actors: insights from the Port of Rotterdam and the Port of Barcelona”. Journal of Transport Geography Vol. 41 pp. 197-209.

Van de Ven, A.H. \& Huber G.P. (1990). Longitudinal field research methods for studying processes of organizational change. Organization science Vol. 1 No 3, pp.213-219.

Volberda, H.W. and Lewin, A.Y. (2003), “Co $\square$ evolutionary dynamics within and between firms: From evolution to co-evolution”. Journal of Management Studies Vol. 40 No. 8) pp. 2111-2136.

Williams, B. (2014), "14 Multiple retailing and brand image", Adding Value (RLE Marketing): Brands and Marketing in Food and Drink, , pp. 291.

Williams, B. (1994a), The best butter in the world : a history of Sainsbury's, Ebury, London

Williams, B. (1994b) Multiple Retailing and Brand Image: An Anglo-American Comparison, 1860-1994“ in Jones, G., and Morgan, N.J. (eds) Adding Value: Brands and Marketing in Food and Drink, Routledge: New York

Williams, B. (2007a). "14 Multiple retailing and brand image." Adding Value (RLE Marketing): Brands and Marketing in Food and Drink ,291.

Williams, B. (2007b). "The value of Sainsbury's sales data in assessing the impact of selfservice methods on food retailing in postwar Britain" Working Paper, University of Reading

Zettinig, P. and Benson-Rea, M. (2008), "What becomes of international new ventures? A coevolutionary approach”. European Management Journal Vol. 26 No 6, pp. 354-365. 